\title{
Virus C genotype predisposes to primary hypothyroidism during interferon- $\alpha$ treatment for chronic hepatitis C
}

\begin{abstract}
Objective: The treatment of the chronic hepatitis C (HCV) with a-interferon is associated with thyroid dysfunction (TD). The aim of this study was to evaluate thyroid function outcome among patients with chronic HCV under treatment with conventional interferon (IFN) or peguilated interferon (PEG-IFN) in association with ribavirin. Patients and Methods: We studied 293 patients with chronic HCV, submitted to drug therapy for 24 or 48 weeks. Initially, we evaluated FT4, TSH, TPOAb, TgAb, and continued to monitor FT4 and TSH every three months during therapy and six months thereafter. Results: At baseline, TD prevalence was $6.82 \%(\mathrm{n}=20) ; 6.14 \%$ hypothyroidism; $0.68 \%$ hyperthyroidism. TPOAb was present in $5.46 \%$ of euthyroid patients. Out of 273 euthyroid patients at baseline, 19\% developed TD: 17.2\% hypothyroidism; $1.8 \%$ hyperthyroidism; $5.1 \%$ destructive thyroiditis (DT). $90 \%$ of TPOAb-positive patients at baseline developed hypothyroidism vs $14.5 \%$ of TPOAb-negative patients $(\mathrm{p}<0.001)$. On average, TD occurred after $25.8 \pm 15.5$ weeks of treatment. $87.2 \%$ of patients who developed hypothyroidism did so during the first therapeutic cycle $(p=0.004$; $\mathrm{OR}=3.52 ; 95 \% \mathrm{CI}=1.36-9.65)$. Patients infected with genotype 1 virus were 2.13 times more likely to develop hypothyroidism $(\mathrm{p}=0.036$; 95\% CI $=1.04-4.38)$. Hypothyroid and DT patients presented higher TSH levels before-treatment than patients who had remained euthyroid ( $\mathrm{p}<0.001 ; \mathrm{p}=0.002$, respectively). DT patients presented lower qALT $(\mathrm{p}=0.012)$ than euthyroid patients. Conclusion: Hypothyroidism was the most frequent TD, especially during the first cycle of $\alpha$-interferon. Genotype 1 virus was associated with a risk two times higher for developing the illness. There was no need to interrupt or to change HCV treatment. Therefore, approximately $34 \%$ of TD was transient.
\end{abstract}

Keywords: hypothyroidism; hepatitis C, chronic; interferon- $\alpha$.

\section{INTRODUCTION}

Hepatitis C virus (HCV) affects from 1.5\% to $2.5 \%$ of the Western population, and is the most common source of infections transmitted by blood transfusions. HCV should be diagnosed as early as possible as most patients without treatment develop hepatic cirrhosis and, eventually, hepatocellular carcinoma. ${ }^{1}$

Interferon- $\alpha($ IFN- $\alpha)$ is a good option for treating HCV. The antiviral action and modulatory effect of the drug on the autoimmune response may elicit a production of antinuclear, antithyroid antibodies, as well as amplification of cellular cytotoxic response. Treatment using IFN- $\alpha$ and ribavirin (RBV), a synthetic guanosine-nucleotide analog, increased remission rates from $20 \%$ to $40 \%$. The therapeutic efficacy of this regimen can be explained by the immunomodulatory and anti-inflammatory additional effects of RBV. Hence, this combined treatment favors the development of systemic and organ-specific autoimmune diseases, such as autoimmune thyroid disease (ATD) and thyroid dysfunction (TD). ${ }^{2-4}$

Patients infected with HCV present $40-$ $42 \%$ of detectable antithyroid autoantibody levels; whereas in patients with hepatitis $B$ virus, the index varies from 5 to $10 \% .{ }^{4}$ The prevalence of TD in patients under IFN- $\alpha$ use ranges from 1 to $35 \%$, possibly due to the lack of standardization for the routine screening of thyroid function evaluation in several studies. TD resulting from the use of
Authors

Maria Helena Postal Pavan ${ }^{1}$ Elizabeth João Pavin ${ }^{2}$ Fernando Lopes Gonçales Jr ${ }^{3}$ Denise Engelbrecht Zantut Wittmann $^{2}$

${ }^{1} \mathrm{MSc} ; \mathrm{MD}$, Infectology, Medical School, Universidade Estadual de Campinas

(FCM-UNICAMP), Campinas, SP, Brazil

${ }^{2} \mathrm{PhD}$; Professors of

Endocrinology,

FCM-UNICAMP, Campinas, SP, Brazil

${ }^{3} \mathrm{PhD}$, Professor of Infectology, FCM-UNICAMP, Campinas, SP, Brazil
Submitted on: 02/02/2011 Approved on: 04/26/2011

Correspondence to: Maria Helena Postal Pavan Rua Tessalia Vieira de Camargo, 126 Barao Geraldo 13084-971, Campinas, SP, Brazil

Phone: (55) (19) 35217727 mariahpavan@yahoo.com.br

We declare no conflict of interest.

(C)2011 Elsevier Editora Ltda. All rights reserved. 
IFN- $\alpha$ presents a wide spectrum of forms and intensities, such as thyrotoxicosis in 2-3\% and hypothyroidism in $2.4-19 \%$ of the cases. ${ }^{4-6} \mathrm{TD}$ is frequently associated with the female gender and HCV-related factors. ${ }^{7}$ There seems to be no correlation between TD and IFN- $\alpha$ dosage; however, the duration of treatment may interfere. Additionally, various authors have reported that $50 \%$ of patients with HCV and antithyroperoxidase antibodies detectable prior to IFN- $\alpha$ treatment developed ATD vs. $5.4 \%$ of patients with negative antibodies. ${ }^{5,6}$

Considering that ATD and TD occur frequently during HCV therapy with IFN- $\alpha$ and RBV, there is a recommendation of systematic evaluation for their presence during treatment and follow-up. Once TD is diagnosed, very often the treatment for HCV is unnecessarily interrupted, which drastically reduces therapeutic success. ${ }^{6}$

The aim of the present study was to assess thyroid function at baseline and during treatment for HCV with standard interferon- $\alpha$ (IFN- $\alpha)$ or peguilated interferon- $\alpha$ (PEG-IFN- $\alpha$ ) combined with RBV.

\section{MATERIAL AND METHODS}

\section{Patients}

We prospectively studied 293 patients with $\mathrm{HCV}$, treated with a combined regimen (IFN or PEG-IFN and RBV), and they were followed by the Infectious Disease Service between 2001 and 2007. Other etiologies of chronic hepatitis were excluded and no patients presented hepatitis B or AIDS.

Thyroid function was evaluated in patients before treatment, every three months during treatment and six months after treatment. Patients who presented TD at baseline underwent monthly reassessment; however, they were excluded from the follow-up group, comprised by euthyroid individuals. The patients were from the city Campinas and region, state of São Paulo, an iodine sufficient area.

\section{Therapeutic plan}

All patients were treated with IFN or PEG-IFN and RBV and received 1-3 therapeutic schedules. Treatment for viral genotypes 2 and 3 lasted for 24 weeks, and 48 weeks for genotypes 1 and 4 . IFN was indicated for patients infected by viral genotypes 2 and 3, and PEG-IFN was the first choice for those with genotype 1 or a second option for those with genotypes 2 and 3 who had failed therapy with IFN. Patients weighing less than $75 \mathrm{~kg}$ used PEG-INF- $\alpha 2 b$ (Peg-Intron ${ }^{\circledR}$ ), whereas patients over $75 \mathrm{~kg}$ were treated with PEG-INF- $\alpha$ $2 \mathrm{a}\left(\right.$ Pegasys $\left.^{\oplus}\right)$. Virologic response was assessed at the end of treatment and 24 weeks thereafter.

A subcutaneous IFN dose of $3 \mathrm{MU}$ was administrated three times a week. A subcutaneous PEG-IFN dose of
$180 \mathrm{mg}$ was administrated once a week for Pegasys ${ }^{\varpi}$ and $1.5 \mathrm{mg} / \mathrm{kg} /$ week for Peg-Intron ${ }^{\circ}$. The RBV dose varied from 1,000 to $1,250 \mathrm{mg} /$ day. IFN/PEG-IFN/RBV dose was not modified by the presence of thyroid dysfunction. The patient was referred to the Endocrinology Service when thyroid dysfunction persisted for over 30 days.

\section{Laboratory assessment}

Chronic hepatitis $\mathrm{C}$ diagnosis was investigated through alteration of qALT (ALT of patient/ALT maximum reference values, $R V \leq 1$ ), through the presence of anti$\mathrm{HCV}$ antibody, and was confirmed through the presence of HCV-RNA (qualitative PCR-HCV, Amplicor 2.0, Roche). Viral genotype was determined by Line Probe assay, LIPA HCV, Innogenetics, Gent, Belgium. Hepatic damage was evaluated by biopsy and classified according to the recommendations of the Brazilian Society of Pathology.

Thyroid function was assessed by serum free $\mathrm{T}_{4}$ $\left(\mathrm{FT}_{4}, \quad \mathrm{RV}=0.9-1.8 \mathrm{ng} / \mathrm{dL}\right)$, thyrotrophin (TSH, $\mathrm{RV}=0.41-4.5 \mathrm{mIU} / \mathrm{mL}$ ) (enzyme immunoassay kits, GenBio, San Diego, USA). ATD was verified by the detection of serum antithyroperoxidase (TPOAb, $\mathrm{RV}>76 \mathrm{IU} / \mathrm{mL}$ ) and antithyroglobulin antibodies ( $\mathrm{TgAb}, \mathrm{RV}>120 \mathrm{IU} / \mathrm{mL}$ ) (fluorimetric enzyme immunoassay, Dade Behring Inc., Miami-FL, USA).

\section{Thyroid disorders}

The following thyroid disorders were considered:

- autoimmune thyroid disease: clinical and laboratory euthyroid patients presenting elevated serum levels of TPOAb and/or TgAb;

- subclinical primary hypothyroidism: increased serum TSH levels, less than $10 \mathrm{mUI} / \mathrm{mL}$ with normal $\mathrm{FT}_{4}$ levels;

- evident primary hypothyroidism: increased serum TSH levels with reduced $\mathrm{FT}_{4}$ levels;

- hyperthyroidism: increased $\mathrm{FT}_{4}$ with reduced levels of TSH;

- destructive thyroiditis: transient TD auto-limited. Initial phase of thyrotoxicosis, intermediate phase of hypothyroidism and resolution phase of euthyroidism or permanent primary hypothyroidism.

Thyroid disorders were classified as transient or definitive, depending on whether or not they returned to normal levels after hepatitis treatment withdrawal. Autoimmune etiology was based on the presence of elevated serum levels of TPOAb and/or TgAb.

\section{Statistical analysis}

The sample profile was described by frequency tables of the categorical variables (age, gender, qALT, viral genotype, presence of cirrhosis, liver biopsy, therapeutic regimen, type of INF- $\alpha$ used, total treatment time, event time 
during treatment, sustained virological response, demonstrating the values of absolute (n) and percentage (\%) frequency. Continuous descriptive variables are presented as mean, standard deviation, minimum, maximum and median values. The association between two categorical variables was analyzed by either Chi-square or Fisher's test. The Mann-Whitney test was used to compare numerical variables between patients with and without thyroid dysfunction. The significance level was set at $5 \%$ $(\mathrm{p}<0.05)$. Statistical analyses were performed using the SAS system for Windows (Statistical Analysis System) version 8.02. SAS Institute INC, 1999-2001, Cary, NC, USA.

\section{RESULTS}

Out of 293 patients included in the study, we verified TD prior to the use of IFN in 20 (6.82\%); 18 of them presented primary hypothyroidism (prevalence $=6.14 \%$ ) and two, hyperthyroidism (prevalence $=0.68 \%)($ Table 1$)$. Elevated serum TPOAb levels were detected in 13 (5.46\%), and $\mathrm{TgAb}$ in five (1.68\%) of 238 patients.

After excluding patients with previous TD, we studied 273 euthyroid individuals who were treated with Interferon- $\alpha$ and ribavirin. Table 2 describes the baseline characteristics of the euthyroid study patients prior to treatment. Under treatment, $19 \%(n=52)$ developed TD, $18 \%$ of the men and $27 \%$ of the women $(\mathrm{p}=0.104)$. TD was diagnosed $25.8 \pm 15.5$ weeks after treatment initiation. Hypothyroidism was verified in $17.2 \%(\mathrm{n}=47)$; hyperthyroidism in $1.8 \%(\mathrm{n}=5)$, and $5.1 \%(\mathrm{n}=14)$ presented destructive thyroiditis (DT).

Table 1. Baseline characteristics of patients with chronic hepatitis $C$ and thyroid dysfunction before treatment with IFN- $\alpha$

\begin{tabular}{lcc}
\hline $\begin{array}{l}\text { Patients } \\
(\mathbf{n}=\mathbf{2 0})\end{array}$ & Hypothyroidism & Hyperthyroidism \\
\hline $\mathrm{n}$ & 18 & 2 \\
\hline $\begin{array}{l}\text { Gender } \\
\text { Female }\end{array}$ & $6 / 92(6.5 \%)$ & 0 \\
$\quad$ Male & $12 / 236(5.1 \%)$ & 2 \\
\hline $\begin{array}{l}\text { Age } \\
\text { (years) }\end{array}$ & $47.9 \pm 9.6$ & 36.5 \\
\hline TPOAb & (median $=46)$ & \\
\hline TgAb & $5 / 15(33 \%)$ & 0 \\
\hline $\begin{array}{l}\text { Sustained virological } \\
\text { response }\end{array}$ & $1 / 16(6.25 \%)$ & 0 \\
\hline Yes & & \\
No & $8(44.4 \%)$ & 0 \\
\hline Virus C genotype & $10(55.6 \%)$ & $1 / 1$ \\
1 & & \\
2 & $12(66.7 \%)$ & 1 \\
3 & $1(5.5 \%)$ & 0 \\
& $5(27.8 \%)$ & 1 \\
\hline
\end{tabular}

Table 2. Baseline characteristics of euthyroid patients with chronic hepatitis $C$ before treatment with IFN- $\alpha$

\begin{tabular}{|c|c|}
\hline \multicolumn{2}{|c|}{ Patients $(n$ total = 273) } \\
\hline Female & $74(27.1 \%)$ \\
\hline Male & 199 (72.9\%) \\
\hline Age (years) & $43.9 \pm 9.7(18-71)$ \\
\hline qALT & $2.49 \pm 1.7(0.3-13.7)$ \\
\hline $\begin{array}{l}\text { Cirrhosis } \\
\text { Yes } \\
\text { No }\end{array}$ & $\begin{array}{c}46(17.3 \%) \\
220(82.7 \%)\end{array}$ \\
\hline $\begin{array}{l}\text { Liver biopsy } \\
\text { Structural alterations } \\
0 / 1 \\
2 \\
3 \\
4\end{array}$ & $\begin{array}{c}37(14.6 \%) \\
120(47.4 \%) \\
61(24.1 \%) \\
35(13.8 \%)\end{array}$ \\
\hline $\begin{array}{c}\text { Activity } \\
0 / 1 \\
2 \\
3 \\
\end{array}$ & $\begin{array}{l}17(13.2 \%) \\
67(51.9 \%) \\
45(34.9 \%)\end{array}$ \\
\hline $\begin{array}{l}\text { Virus C genotype } \\
1 \\
2 \\
3 \\
\end{array}$ & $\begin{array}{c}151(57.8 \%) \\
7(2.7 \%) \\
103(39.4 \%)\end{array}$ \\
\hline $\begin{array}{l}\text { Number of therapeutic regimens } \\
\quad \begin{array}{l}1 \\
\geq 2\end{array}\end{array}$ & $\begin{array}{c}177(64.8 \%) \\
96(35.2 \%)\end{array}$ \\
\hline $\begin{array}{l}\text { Treatment duration } \\
\quad<48 \text { weeks } \\
\quad \geq 48 \text { weeks }\end{array}$ & $\begin{array}{l}123(45.2 \%) \\
149(54.8 \%)\end{array}$ \\
\hline $\begin{array}{l}\text { Total treatment duration } \\
\text { (weeks) }\end{array}$ & $37.7 \pm 14.0(8-120)$ \\
\hline $\begin{array}{l}\text { Interferon used } \\
\text { IFN } \\
\text { PEG }\end{array}$ & $\begin{array}{l}194 \\
165\end{array}$ \\
\hline $\begin{array}{l}\text { End of treatment response } \\
\text { Yes } \\
\text { No }\end{array}$ & $\begin{array}{c}184(68.4 \%) \\
85(31.6 \%) \\
\end{array}$ \\
\hline $\begin{array}{l}\text { Sustained virological response } \\
\text { Yes } \\
\text { No }\end{array}$ & $\begin{array}{l}144(54.7 \%) \\
119(45.2 \%) \\
\end{array}$ \\
\hline Free $\mathrm{T}_{4}(\mathrm{ng} / \mathrm{dL})$ & $1.21 \pm 0.19$ \\
\hline TSH (mIU/L) & $1.93 \pm 0.89$ \\
\hline TPOAb > $76 \mathrm{IU} / \mathrm{ml}($ total $\mathrm{n}=200)$ & $8(4.0 \%)$ \\
\hline TgAb > 120 IU/mL (total $\mathrm{n}=199$ ) & $3(1.5 \%)$ \\
\hline
\end{tabular}

$\mathrm{FT}_{4}, \mathrm{RV}=0.9-1.8 \mathrm{ng} / \mathrm{dL} \mathrm{TSH}, \mathrm{RV}=0.41-4.5 \mathrm{mIU} / \mathrm{L}$. TPOAb (RV $\leq 76 \mathrm{IU} / \mathrm{mL}) \mathrm{TgAb}, \mathrm{RV} \leq 120 \mathrm{IU} / \mathrm{mL}$.

Among the 13 patients presenting high TPOAb levels before using INF- $\alpha$, five had a previous diagnosis of primary hypothyroidism. During the first therapeutic regimen, seven out of eight euthyroid 
patients became hypothyroid. Therefore, $90 \%$ of TPOAb-positive patients before treatment developed hypothyroidism vs. $14.5 \%$ of TPOAb-negative patients $(\mathrm{p}<0.001)$. Moreover, 10 patients were infected with genotype 1 virus (76.9\%); one patient with genotype 2 virus; and one with genotype 3 (one patient did not have the genotype identified).

Table 3 lists the characteristics of patients who developed hypothyroidism under treatment. 87.2\% of the patients presented hypothyroidism during the first therapeutic regimen $(\mathrm{p}=0.004 ; \mathrm{OR}=3.52$;

Table 3. Characteristics of patients who developed primary hypothyroidism under IFN- $\alpha$ treatment

\begin{tabular}{|c|c|}
\hline \multicolumn{2}{|c|}{ Hypothyroid $(n=47)$} \\
\hline Female & $16(34.0 \%)$ \\
\hline Male & $31(66.0 \%)$ \\
\hline Age (years) & $44.6 \pm 9.3(25-68)$ \\
\hline qALT & $2.35 \pm 1.61(0.7-7.6)$ \\
\hline $\begin{array}{l}\text { Cirrhosis } \\
\text { Yes } \\
\text { No }\end{array}$ & $\begin{array}{c}8(17.0 \%) \\
39(83.0 \%)\end{array}$ \\
\hline $\begin{array}{l}\text { Liver biopsy } \\
\text { Structural alter } \\
0 / 1 \\
2 \\
3 \\
4\end{array}$ & $\begin{array}{c}4(8.5 \%) \\
20(42.5 \%) \\
14(29.8 \%) \\
7(14.9 \%)\end{array}$ \\
\hline $\begin{array}{l}\text { Virus C genotype } \\
1 \\
2 / 3\end{array}$ & $\begin{array}{l}31(72.1 \%) \\
12(27.9 \%)\end{array}$ \\
\hline $\begin{array}{l}\text { Event time under } \\
\text { treatment (weeks) }\end{array}$ & $26.52 \pm 16.49(8-96$, median = 24) \\
\hline $\begin{array}{l}\text { Number of therap } \\
\text { regimens at the ev } \\
1 \\
2\end{array}$ & $\begin{array}{c}41(87.2 \%) \\
6(12.8 \%)\end{array}$ \\
\hline $\begin{array}{l}\text { Total treatment } \\
\text { duration (weeks) }\end{array}$ & $43.02 \pm 15.64(24-96 ;$ median = 48) \\
\hline $\begin{array}{l}\text { Interferon used } \\
\text { IFN } \\
\text { PEG } \\
\text { IFN+PEG }\end{array}$ & $\begin{array}{l}14(29.8 \%) \\
13(27.6 \%) \\
20(42.5 \%)\end{array}$ \\
\hline $\begin{array}{l}\text { Final virological re } \\
\text { Yes } \\
\text { No }\end{array}$ & $\begin{array}{l}31(68.9 \%) \\
14(31.1 \%) \\
\end{array}$ \\
\hline $\begin{array}{l}\text { Sustained virologi } \\
\text { response }(\mathrm{n}=254) \\
\text { Yes } \\
\text { No }\end{array}$ & $\begin{array}{l}26(57.8 \%) \\
19(42.2 \%)\end{array}$ \\
\hline Free T4 (ng/dL) & $0.79 \pm 0.38(0.04-1.6 ;$ median $=0.80)$ \\
\hline TSH (mIU/L) & $27.5 \pm 30.5(4.7-100.0 ;$ median $=9.48)$ \\
\hline
\end{tabular}

$\mathrm{FT}_{4}, \mathrm{RV}=0.9-1.8 \mathrm{ng} \% \mathrm{TSH}, \mathrm{RV}=0.41-4.5 \mathrm{mIU} / \mathrm{L}$
95\% CI $=1.36-9.65)$. The logistic regression analysis related to categorical variables established that patients infected with genotype 1 virus were 2.13 times more likely to develop primary hypothyroidism ( $\mathrm{p}=0.036$; $95 \% \mathrm{CI}=1.04-4.38)$ during treatment. The variables age $(p=0.326)$, gender $(p=0.197)$, presence of cirrhosis $(\mathrm{p}=0.984)$, liver biopsy characteristics (structural alterations, $p=0.498$ and activity, $p=0.892$ ), use of IFN $(\mathrm{p}=0.755)$ or PEG-IFN ( $\mathrm{p}=0.153)$, type of PEG-IFN used $(\mathrm{p}=0.766)$ and sustained virological response $(\mathrm{p}=0.946)$ were not significantly associated with TD.

Regarding patients under treatment, the euthyroid group had higher TSH serum levels before treatment $($ mean $=1.78$ vs. $2.59 ;$ median $=1.6$ vs. $2.72, \mathrm{p}<0.001)$ than the group that developed hypothyroidism. There was no significant difference between the two groups in relation to age $(\mathrm{p}=0.567)$, weight $(\mathrm{p}=0.148), \mathrm{FT}_{4}$ levels before treatment $(\mathrm{p}=0.126)$ and $\mathrm{qALT}(\mathrm{p}=0.219)$. Table 4 describes the types of TD encountered in this study.

Hyperthyroidism was confirmed in a small number of patients $(\mathrm{n}=5)$, allowing only for descriptive analysis (Table 5).

Table 6 describes characteristics of the 14 patients who triggered DT during treatment. Comparing to those without such complication, DT patients were not significantly different in terms of age $(p=0.334)$, weight $(p=0.372)$, gender $(p=0.755)$, presence of cirrhosis $(\mathrm{p}=1.000)$, liver biopsy characteristics (structural alterations, $p=0.701$ and activity, $p=0.239$ ), use of IFN ( $p=0.765)$ or PEG-IFN ( $p=0.147)$, type of PEG-IFN used $(\mathrm{p}=0.510)$, sustained virological response $(\mathrm{p}=0.823)$ and viral genotype $(\mathrm{p}=0.082)$.

The comparative analysis of continuous variables between the euthyroid group and the DT group of patients under treatment, demonstrated that the latter presented TSH levels significantly higher before treatment ( mean $=1.78$ vs. 2.55 ; median $=1.6$ vs. $2.72, \mathrm{p}=0.002)$, as well as lower qALT $($ mean $=1.68$, median $=2.10$ vs. 1.35 , $\mathrm{p}=0.012)$. The comparison between the two groups regarding age $(\mathrm{p}=0.096)$, weight $(\mathrm{p}=0.372)$, and $\mathrm{FT}_{4}$ levels prior to treatment $(\mathrm{p}=0.727)$ was not significant.

Table 4. Length and intensity of thyroid dysfunction

\begin{tabular}{lcc}
\hline & $\begin{array}{c}\text { Hypothyroidism } \\
(\mathbf{n}=47)\end{array}$ & $\begin{array}{c}\text { Hyperthyroidism } \\
(\mathbf{n}=5)\end{array}$ \\
\hline Transient & $17(36.2 \%)$ & $1(20 \%)$ \\
\hline Definitive & $30(63.8 \%)$ & $4(80 \%)$ \\
\hline Subclinical & $20(42.5 \%)$ & $3(60 \%)$ \\
\hline Manifest & $27(57.5 \%)$ & $2(40 \%)$
\end{tabular}


Table 5. Patients who developed hyperthyroidism under IFN- $\alpha$ treatment

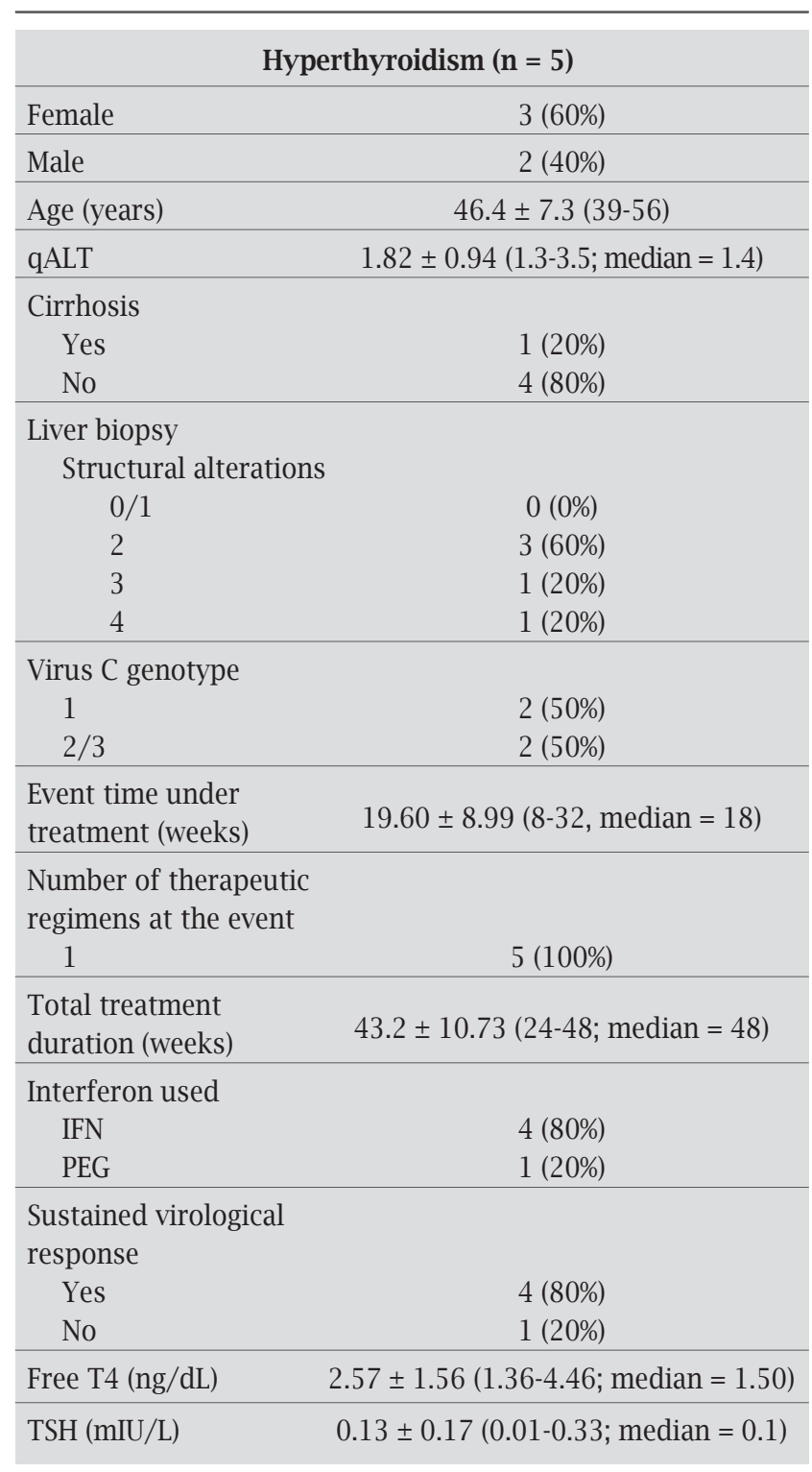

$\mathrm{FT}_{4}, \mathrm{RV}=0.9-1.8 \mathrm{ng} \% \mathrm{TSH}, \mathrm{RV}=0.41-4.5 \mathrm{mIU} / \mathrm{L}$.

\section{DISCUSSION}

Hepatitis $\mathrm{C}$ virus is a hepatotropic and lymphotropic RNA virus which may be associated with chronic infectious disease. ${ }^{8}$ Although hepatocytes are the major site of HCV replication, extrahepatic complications of HCV infection may occur, such as autoimmune diseases and lymphoproliferative disorders. ${ }^{9}$

$\mathrm{HCV}$ treatment with IFN- $\alpha$ and RBV can trigger adverse effects frequently leading to a reduction of the dose in over $40 \%$ of the patients or even withdrawal in approximately $14 \% .{ }^{8}$

Standard or PEG-IFN- $\alpha$ may lead to influenza-like symptoms at the onset of treatment, as well as psychiatric, hematologic (neutropenia and thrombocytopenia) ${ }^{10,11}$ and
Table 6. Patients who developed destructive thyroiditis under IFN- $\alpha$ treatment

\begin{tabular}{|c|c|}
\hline \multicolumn{2}{|c|}{ Patients $(n=14)$} \\
\hline Female & $4(28.5 \%)$ \\
\hline Male & $10(71.5 \%)$ \\
\hline Age (years) & $40.0 \pm 8.0(30-60)$ \\
\hline qALT & $1.68 \pm 1.10(0.8-6.6 ;$ median $=1.3)$ \\
\hline $\begin{array}{l}\text { Cirrhosis } \\
\text { Yes } \\
\text { No }\end{array}$ & $\begin{array}{c}2(14.3 \%) \\
12(87.7 \%)\end{array}$ \\
\hline $\begin{array}{l}\text { Liver biopsy } \\
\text { Structural alterat } \\
\quad 0 / 1 \\
2 \\
3 \\
4 \\
\end{array}$ & $\begin{array}{l}3(23.0 \%) \\
5(38.5 \%) \\
4(30.7 \%) \\
1(7.6 \%)\end{array}$ \\
\hline $\begin{array}{l}\text { Virus C genotype } \\
\begin{array}{l}1 \\
2 / 3\end{array}\end{array}$ & $\begin{array}{c}11(78.5 \%) * \\
3(21.4 \%)\end{array}$ \\
\hline $\begin{array}{l}\text { Event time under } \\
\text { treatment (weeks) }\end{array}$ & $19.60 \pm 8.99(8-32$, median $=18)$ \\
\hline $\begin{array}{l}\text { Number of therapeu } \\
\text { regimens at the ever } \\
1 \\
2\end{array}$ & $\begin{aligned} 13 & (92.8 \%) \\
1 & (7.4 \%)\end{aligned}$ \\
\hline $\begin{array}{l}\text { Total treatment } \\
\text { duration (weeks) }\end{array}$ & $42.86 \pm 10.22(24-48 ;$ median $=48)$ \\
\hline $\begin{array}{l}\text { Interferon used } \\
\text { IFN } \\
\text { PEG }\end{array}$ & $\begin{array}{l}8(57.1 \%) \\
6(42.8 \%) \\
\end{array}$ \\
\hline $\begin{array}{l}\text { Sustained virologica } \\
\text { response } \\
\text { Yes } \\
\text { No }\end{array}$ & $\begin{array}{l}8(57.1 \%) \\
6(42.8 \%) \\
\end{array}$ \\
\hline $\begin{array}{l}\text { Outcome } \\
\text { Hypothyroidism } \\
\text { Euthyroidism }\end{array}$ & $\begin{array}{c}10(71.5 \%) \\
4(28.5 \%)\end{array}$ \\
\hline
\end{tabular}

thyroid dysfunction. ${ }^{12}$ As referred by Sachithanandan et al., ${ }^{13}$ thyropathies affect $26.3 \%$ of HCV treated patients. The association with RBV usually induces hemolytic anemia, with no additional risk of thyropathy. ${ }^{10}$

Generally, SVR is achieved in approximately $60 \%$ of the patients, $40 \%$ among patients of viral genotype 1 and $76 \%$ among those with viral genotypes 2 and 3 . Other SVR predictive factors include: age less than 40 years, weight lower than $75 \mathrm{~kg}$, female gender, Caucasian race, low viral load before treatment, and absence of liver cirrhosis. ${ }^{10}$ In our study, HCV patients obtained $53.9 \%$ as response rate of IFN- $a$ therapy, in accordance to the literature. The study population showed a predominance of Caucasoid male patients infected by virus $C$ of genotypes 1 and 3 . 
Based on the literature, ${ }^{2}$ standard IFN was indicated for patients infected with virus of genotypes 2 and 3, and PEG-IFN was the first choice for genotype 1. Nonresponding patients with genotypes 2 and 3 could then be treated with PEG-IFN. More than one therapeutic regimen was prescribed to $35.2 \%$ of the patients, and $54.8 \%$ of them were treated for 48 weeks. PEG-IFN was administrated to 165 patients: those who weighed less than $75 \mathrm{~kg}$ used PEG-IFN- $\alpha 2 \mathrm{~b}$ and those with more than $75 \mathrm{~kg}, \mathrm{PEG}-\mathrm{IFN}-\alpha 2 \mathrm{a}$.

Firstly, Pateron et al. ${ }^{14}$ reported a prevalence of $14 \%$ of antithyroid autoantibodies in $\mathrm{HCV}$ patients. A review of published controlled studies ${ }^{15}$ observed that most reports confirmed a higher prevalence of autoimmune thyroid disease and hypothyroidism in chronic HCV-infected patients.

Several studies found that female gender and the presence of TPOAb were considered major risk factors for the development of hypothyroidism. ${ }^{16-19}$ Our data demonstrated that TPOAb-positive patients had a higher chance of developing hypothyroidism; however, females were not more prone, similarly to the findings reported by Muratori et al. ${ }^{20}$ and Stefanova-Petrova et al. ${ }^{21}$

The prevalence of hypothyroidism in $\mathrm{HCV}$ patients is approximately $9 \%(0-13 \%)$ vs. $3 \%(0.5-4 \%)$ in healthy subjects. ${ }^{19,22-24}$ Thyroid autoimmunity was demonstrated in $15 \%$ (5-28\%) of the HCV patients and in $12 \%$ (0-11\%) of healthy subjects, indicating a slight though significantly higher risk. ${ }^{15}$ In our study, we verified that the prevalence of hypothyroidism $(6.1 \%)$ and thyroid autoimmunity (5.5\%) found in HCV patients before treatment was similar to the literature reports, in spite of the differences existing in geographical distribution, genetic variability, iodine intake or other infectious agents. ${ }^{25,26}$ Moreover, the prevalence of hyperthyroidism before IFN- $\alpha$ treatment $(0.68 \%)$ found in our study population was not significantly different in $\mathrm{HCV}$-infected patients, as described in the literature. ${ }^{15}$

After IFN-a therapy, 19\% presented thyroid dysfunction: hypothyroidism in $17.2 \%$, hyperthyroidism in $1.8 \%$ and destructive thyroiditis in $5.1 \%$ - very similar values were found by Sachithanandan et al. ${ }^{13}$ (26.3\%), higher than those described by Moncoucy et al. ${ }^{27}(7 \%)$ and Tran et al. ${ }^{16}(6.7 \%)$.

The rates of thyroid dysfunction triggered by the two types of IFN- $\alpha$, standard and peguilated, were similar, as also found by Moncoucy et al. ${ }^{27}$ Moreover, thyroid dysfunction was not associated with sustained virological response of chronic hepatitis C to IFN- $\alpha$ therapy, as also demonstrated by Hsieh et al. ${ }^{28}$ and in contrast to previous reports. ${ }^{29-31}$ In our patients, the presence of thyroid dysfunction did not lead to changes in the dose or therapy withdrawal.

After IFN-a plus RBV treatment $17.2 \%$ developed primary hypothyroidism. However, this rate has varied in several studies. ${ }^{16,27}$ Among risk factors evaluated: age, gender, presence of cirrhosis, qALT and $\mathrm{FT}_{4}$ levels before treatment, type and commercial presentation of IFN- $\alpha$ used, and SVR, we found no association with primary hypothyroidism. In contrast, the likelihood of developing primary hypothyroidism increased in the presence of TPOAb, genotype 1 , to be on the first therapeutic regimen, and having higher TSH levels before treatment. This last finding was also observed by Antonelli et al. ${ }^{19}$

Detection of TPOAb before therapy was associated with a risk 3.5 times greater of becoming hypothyroid on IFN- $\alpha$ use; $90 \%$ of such patients in our study developed the dysfunction vs. $14.5 \%$ of TPOAb-negative, corroborating Prummel and Laurberg, ${ }^{7}$ who found a relative risk of 3.9. Elevated endogenous interferon in response to viral diseases could possibly be associated with the development of IFN- $\alpha$ induced thyroiditis by in genetically predisposed individuals. ${ }^{17,27,32-34}$

Prummel and Laurberg ${ }^{7}$ have demonstrated that the female gender has a relative risk of 4.4 for developing autoimmune thyroiditis. This strong preponderance may perhaps be due to the effects of estrogen or secondary to $\mathrm{X}$ chromosome susceptibility genes. ${ }^{35,36}$ This fact was not corroborated by our study, as well as by Muratori et al. ${ }^{20}$ and Stefanova-Petrova et al. ${ }^{21}$ It is important to highlight that thyroid dysfunction could result from a direct effect of IFN- $\alpha$ on thyroid cell function. . $^{2,37,38}$

The higher prevalence of virus $\mathrm{C}$ genotype 1 in patients who developed hypothyroidism is not a consensus in the literature. Sachithanandan et al. ${ }^{13}$ have detected elevated TPOAb levels before and during therapy only in genotype 1 patients. Conversely, Huang et al. ${ }^{34}$ observed higher prevalence of genotype $1 \mathrm{~b} / 2 \mathrm{~b}$ in women with hepatitis $\mathrm{C}$ and detectable TPOAb, but with no correlation with hypothyroidism. Viral replication results in the production of a heterogeneous viral population within an infected individual. ${ }^{39}$ Some authors suggested that a portion of the $\mathrm{HCV}$ genome could share a partial sequence homology in a few amino acid segments with thyroglobulin and microsome, rendering $\mathrm{HCV}$ patients susceptible to autoimmune thyroid diseases. ${ }^{28}$ This hypothesis could explain the relation between viral genotype and the predisposition to develop thyroid diseases in patients infected by virus $C$ genotype 1 , as verified in our patient population.

In the present study, patients had a relative risk of 3.5 for developing hypothyroidism during the first treatment course; however, Moncoucy et al. ${ }^{27}$ found no difference in thyroid dysfunction rate between first and second courses of treatment. Previous studies have reported that thyroid dysfunction induced by IFN-a could develop in the first week or after a few months, during and after therapy, with a possible contribution of cumulative dose. ${ }^{17,29,32}$ Nevertheless, the underlying mechanism remains unclear. The immunomodulatory action of IFN- $\alpha$ in susceptible patients ${ }^{38,40-42}$ could affect the thyroid hormone syn- 
thesis and secretion in vitro. ${ }^{43}$ Our data did not suggest a cumulative dose-effect, as only a few patients did not present thyroid dysfunction during the first treatment. Interestingly, after drug withdrawal, $64 \%$ of the patients remained hypothyroid, requiring L-thyroxin replacement therapy, and the other patients presented the subclinical form of the disease.

Hyperthyroidism seems a rare event during IFN- $\alpha$ therapy and was verified in $1.8 \%$ of the patients. Several studies found even lower prevalence of hyperthyroidism, ranging from $0.9 \%$ to $1.1 \% .{ }^{16,27,29,44}$

Destructive thyroiditis occurred in $5.1 \%$ of our patients and approximately $70 \%$ developed permanent hypothyroidism. Almost 50\% of non-autoimmune IFN- $\alpha$-induced thyroiditis manifests such a destructive thyroiditis, a self-limited inflammatory disorder characterized by three phases of six to eight weeks each: thyrotoxicosis, hypothyroidism and resolution to euthyroidism or definitive hypothyroidism in less than $5 \%$ of the cases. The symptoms are usually mild, probably leading to a lower diagnostic rate; however, atrial fibrillation may occur. ${ }^{8,45}$ We observed that TSH levels before treatment were higher and qALT was lower in patients who developed destructive thyroiditis under IFN- $\alpha$. This finding has not been previously reported in the literature. Some authors found recurrent thyroiditis during retreatment ${ }^{46}$ however, in our study, $98 \%$ of the patients developed destructive thyroiditis only during the first treatment.

We concluded that in the screening for predictive factors of thyroid dysfunction in HCV patients before treatment with IFN- $\alpha$ it is especially important to evaluate TSH levels, as well as antithyroid antibodies and viral genotype. Moreover, the first contact with IFN- $\alpha$ holds substantial risk to develop thyroid dysfunction. Special care is essential when there are laboratory alterations indicating thyrotoxicosis, which may be signaling an initial phase of destructive thyroiditis, a benign and self-limited disturbance. We emphasize that a significant part of the dysfunction was transient or subclinical, not requiring treatment.

\section{REFERENCES}

1. Bellentani S, Tiribelli C. The spectrum of liver disease in the general population: lessons from the Dionysos study. J Hepatol 2001; 35:531-7.

2. Poynard T, Marcellin P, Lee SS et al. Randomized trial of interferon a $2 b$ plus ribavirin for 48 weeks or for 24 weeks versus interferon a $2 \mathrm{~b}$ plus placebo for 48 weeks for treatment of chronic infection with hepatitis C virus. Lancet 1998; 352:1426-32.

3. Tam RC, Pai B, Bard J et al. Ribavirin polarizes human T cell responses toward a type 1 cytokine profile. J Hepatol 1999; 30:376-82.

4. Koh LKH, Greenspan FS, Yeo PPB. Interferon-a induced thyroid dysfunction: three clinical presentations and review of the literature. Thyroid 1997; 7:891-6.
5. Dalgard O, Bjoro K, Hellum K et al. Thyroid dysfunction during treatment of chronic hepatitis $\mathrm{C}$ with interferon-a: no association with either interferon dosage or efficacy of therapy. J Int Med 2002; 251:400-6.

6. Carella C, Mazziotti G, Amato G et al. Interferon- $\alpha$ related thyroid disease: pathophysiological, epidemiological, and clinical aspects. J Clin Endocrinol Metab 2004; 89:3656-61.

7. Prummel MF, Lauberg P. Interferon- $\alpha$ and autoimmune thyroid disease. Thyroid 2003;13:547-51.

8. Tomer Y, Blackard JT, Akeno N. Interferon alpha treatment and thyroid dysfunction. Endocrinol Metab Clin N Am 2007; 36:1051-66.

9. Blackard JT, Kemmer N, Sherman KE. Extrahepatic replication of HCV: insights into clinical manifestations and biological consequences. Hepatology 2006;44:15-22.

10. Fried MW. Side effects of therapy of hepatitis $\mathrm{C}$ and their management. Hepatology 2002; 36:237-44.

11. Evon DM, Verma A, Simpson K et al. Psychiatric symptoms during interferon treatment for hepatitis C: experiences from a tertiary care hepatology centre. Aliment Pharmacol Ther 2008; 27:1071-80

12. Fentiman IS, Thomas BS, Balkwill FR et al. Primary hypothyroidism associated with interferon therapy of breast cancer. Lancet 1985; 8438:1166.

13. Sachithanandan S, Clarke G, Crowe J et al. Interferon-associated thyroid dysfunction in anti-D-related chronic hepatitis C. J Interf Cytok Res 1997; 17:409-11.

14. Pateron D, Hartmann DJ, Duclos-Vallee JC et al. Latent autoimmune thyroid disease in patients with chronic HCV hepatitis. J Hepatol 1992; 16:244-5.

15. Antonelli A, Ferri C, Fallahi $\mathrm{P}$ et al. Thyroid disorders in chronic hepatitis $C$ virus infection. Thyroid 2006;16:563-72.

16. Tran A, Quaranta JF, Benzaken S et al. High prevalence of thyroid autoantibodies in a prospective series of patients with chronic hepatitis C before interferon therapy. Hepatol 1993; 18:253-7.

17. Preziati D, La Rosa L, Covini G et al. Autoimmunity and thyroid function in patients with chronic active hepatitis treated with recombinant interferon alpha-2a. Eur J Endocrinol 1995; 132:587-93.

18. Fernandez-Soto L, Gonzalez A, Escobar-Jimenez F et al. Increased risk of autoimmune thyroid disease in hepatitis $\mathrm{C} v \mathrm{~s}$ hepatitis $\mathrm{B}$ before, during, and after discontinuing interferon therapy. Arch Int Med 1998; 158:1445-8.

19. Antonelli A, Ferri C, Pampana A et al. Thyroid disorders in chronic hepatitis C. Am J Med 2004; 117:10-13.

20. Muratori L, Bogdanos DP, Muratori P et al. Susceptibility to thyroid disorders in hepatitis C. Clin Gastroenterol Hepatol 2005; 3:595-603.

21. Stefanova-Petrova DV, Tzvetanska AH, Naumova EJ et al. Chronic hepatitis $\mathrm{C}$ virus infection: prevalence of extrahepatic manifestations and association with cryoglobulinemia in Bulgarian patients. World J Gastroenterol 2007; 13:6518-28.

22. Matsuda J, Saitoh N, Gotoh M et al. High prevalence of antiphospholipid antibodies and anti-thyroglobulin antibody in patients with hepatitis $\mathrm{C}$ virus infection treated with interferon-alpha. Am J Gastroenterol 1995; 90:1138-41.

23. Custro N, Montalto G, Scafidi V et al. Prospective study on thyroid autoimmunity and dysfunction related to chronic hepatitis C and interferon therapy. J Endocrinol Invest 1997; 20:374-80.

24. Boadas J, Rodríguez-Espinosa J, Enríquez J et al. Prevalence of thyroid autoantibodies is not increased in blood donors with hepatitis C virus infection. J Hepatol 1995; 22:611-5. 
25. Prentice LM, Phillips DI, Sarsero D et al. Geographical distribution of subclinical autoimmune thyroid disease in Britain: a study using highly sensitive direct assays for autoantibodies to thyroglobulin and thyroid peroxidase. Acta Endocrinol 1990;123:493-8.

26. Minelli R, Braverman LE, Giuberti T et al. Effects of excess iodine administration on thyroid function in euthyroid patients with a previous episode of thyroid dysfunction induced by interferon-alpha treatment. Clil Endocrinol 1997; 47:357-61.

27. Moncoucy X, Leymarie F, Delemer B et al. Risk factors and long-term course of thyroid dysfunction during antiviral treatments in 221 patients with chronic hepatitis C. Gastroenterol Clin Biolog 2005; 29:339-45.

28. Hsieh MC, Yu ML, Chuang WL et al. Virologic factors related to interferon-alpha-induced thyroid dysfunction in patients with chronic hepatitis C. Eur J Endocrinol 2000; 142:431-7.

29. Lisker-Melman M, Di Bisceglie AM, Usala SJ et al. Development of thyroid disease during therapy of chronic viral hepatitis with interferon alfa. Gastroenterol 1992; 102:2155-60.

30. Primo J, Hinojosu J, Molés JR et al. Development of thyroid dysfunction after alpha-interferon treatment of chronic hepatitis C. Am J Gastroenterol 1993; 88:1976-7.

31. Reid I, Sharpe I, McDevitt J et al. Thyroid dysfunction can predict response to immunotherapy with interleukin-2 and interferon-2 alpha. Brit J Cancer 1991; 64:915-8.

32. Watanabe U, Hashimoto E, Hisamitsu T et al. The risk factor for development of thyroid disease during interferon-alpha therapy for chronic hepatitis C. Am J Gastroenterol 1994; 89:399-403.

33. Vanderpump MP, Tunbridge WM, French JM et al. The incidence of thyroid disorders in the community: a twenty-year follow-up of the Whickham Survey. Clin Endocrinol 1995; 43:55-68.

34. Huang JF, Chuang WL, Dai CY et al. The role of thyroid autoantibodies in the development of thyroid dysfunction in Taiwanese chronic hepatitis $C$ patients with interferon-alpha and ribavirin combination therapy. J Vir Hepat 2006; 13:396-401.

35. Grossman CJ, Roselle GA, Mendenhall CL. Sex steroid regulation of autoimmunity. J Ster Biochem Mol Biol 1991; 40:649-59.
36. Tomer Y, Davies TF. Searching for the autoimmune thyroid disease susceptibility genes: from gene mapping to gene function. Endocr Rev 2003; 24:694-717.

37. Carella C, Amato G, Biondi B et al. Longitudinal study of antibodies against thyroid in patients undergoing interferon-alpha therapy for HCV chronic hepatitis. Horm Res 1995; 44:110-4.

38. Katabami S, Kamijo K, Kodama T et al. An episode of silent thyroiditis in a patient with chronic thyroiditis and papillary adenocarcinoma following alpha interferon treatment for hepatitis C. Endocr J 1993; 40:311-6.

39. Simmonds P. Genetic diversity and evolution of hepatitis $\mathrm{C}$ virus - 15 years on. J Gen Virol 2004; 85:3173-88.

40. Gisslinger H, Gilly B, Woloszczuk W et al. Thyroid autoimmunity and hypothyroidism during long-term treatment with recombinant interferon-alpha. Clil Exp Immunol 1992; 90:363-7.

41. Nagayama Y, Ohta K, Tsuruta $\mathrm{M}$ et al. Exacerbation of thyroid autoimmunity by interferon alpha treatment in patients with chronic viral hepatitis: our studies and review of the literature. Endocr J 1994; 41:565-72.

42. Chung YH, Shong YK. Development of thyroid autoimmunity after administration of recombinant human interferonalpha 2b for chronic viral hepatitis. Am J Gastroenterol 1993; 88:244-7.

43. Yamazaki K, Kanaji Y, Shizume K et al. Reversible inhibition by interferons alpha and beta of 125 I incorporation and thyroid hormone release by human thyroid follicles in vitro. J Clin Endocrinol Metab 1993; 77:1439-41.

44. Hollowell JG, Staehling NW, Flanders WD et al. Serum TSH, $\mathrm{T}(4)$, and thyroid antibodies in the United States population (1988 to 1994): National Health and Nutrition Examination Survey (NHANES III). J Clin Endocrinol Metab 2002; 87:489-99.

45. Weetman AP, Smallridge RC, Nutman TB et al. Persistent thyroid autoimmunity after subacute thyroiditis. J Clin Lab Immunol 1987; 23:1-6.

46. Paraná R, Cruz M, Lyra L, Cruz T. Subacute thyroiditis during treatment with combination therapy (interferon plus ribavirin) for hepatitis C virus. J Vir Hepat 2000; 7:393-5. 